\title{
HIV/AIDS SEBAGAI “RUANG” PELAYANAN PASTORAL GEREJA
}

\author{
Robinson Simanungkalit \\ Institusi Agama Kristen Negeri Tarutung \\ Email: aristo simanungkalit@yahoo.co.id
}

\begin{abstract}
Sangatlah penting untuk menjelaskan beberapa hal penting tentang HIV/AIDS guna memberikan pemahaman yang benar tentang HIV/AIDS. Dibutuhkan penjelasan tentang apa itu HIV/AIDS, Sejarah munculnya HIV/AIDS, Penularan HIV/AIDS dan dampak yang ditimbulkan oleh HIV/AIDS terhadap orang- orang yang terinfeksi. Orang yang terinfeksi HIV dan AIDS itu disebut sebagai ODHA (Orang yang hidup dengan HIV dan AIDS). Mungkin saja mereka adalah warga gereja dan karena itu gereja tidak boleh "menutup mata" tetapi dituntut untuk proaktif dalam menyikapi keberadaan warganya yang terinfeksi HIV/AIDS.
\end{abstract}

Kata kunci : HIV/AIDS, ODHA

Abstract : It is important to explain some important things on Human Immunodeficiency Virus (HIV) or Acquired Immunodeficiency Syndrome (AIDS). This study was aimed to to provide a proper understanding on the HIV/AIDS. Consequently, this study described what the HIV/AIDS is, the history of the emergence of HIV/AIDS, the transmission of HIV/AIDS, and the effects of HIV/AIDS on infected human. People infected with HIV and AIDS are referred to as PLWHA (People living with HIV and AIDS). They may be church citizens. Therefore, the church must not "turn a blind eye", but is required to be proactive in responding to people who have infected with HIV/AIDS.

Keywords: $H I V / A I D S, O D H A$

\section{PENDAHULUAN}

HIV (Human Immunnodeficiency Virus) adalah virus yang menyerang sistem kekebalan tubuh manusia dan melemahkan kemampuan tubuh untuk melawan segala penyakit yang datang. Pada saat kekebalan tubuh mulai lemah, maka timbullah masalah gangguan kesehatan. Gejala yang umum timbul antara lain demam, batuk atau diare yang terus-menerus. Kumpulan gejala penyakit akibat lemahnya sistem kekebalan tubuh inilah yang disebut AIDS (Acquired Immuno Deficiency Syndrome). ${ }^{1}$

AIDS adalah penyakit yang menimbulkan permasalahan bagi orang yang terinfeksi dan orang-orang yang berada disekitar mereka. AIDS muncul di Afrika, Amerika Utara, Karibia, dan Eropa kira-kira pada saat yang sama kira-kira di tahun-tahun terakhir abad 20 kasus-kasus dilaporkan dari berbagai penjuru dunia. HIV/AIDS menyebar dengan sangat cepat di Eropa Timur dan Asia termasuk Indonesia. Sampai sekarang HIV/AIDS menjadi masalah besar karena tidak ada vaksin yang mampu menyembuhkan infeksi ini. ${ }^{2}$

\footnotetext{
${ }^{1}$ Yayasan SPIRITIA, Pasien Berdaya - Seri Buku Kecil, Jakarta: Yayasan SPIRITIA, 2001 hal 4

${ }^{2}$ A.Wati Longchar (ed) Compassion and Care for the HIVIAIDS Infected and Affected dalam buku :Health,
}

Di Indonesia orang yang telah terinfeksi HIV dan AIDS disebut sebagai Orang yang hidup dengan HIV dan AIDS (ODHA), sementara mereka yang mempunyai hubungan dekat dengan ODHA seperti keluarga, pasangan dan para pendamping disebut OHIDHA. Dua istilah ini perlu digunakan secara hati-hati dan hanya untuk kepentingan identifikasi metodologi pendampingan saja. Karena penggunaan istilah ini sering menimbulkan stigma dan diskriminasi. ${ }^{3}$ Permasalahan utama yang perlu mendapatkan perhatian dari gereja adalah sikap diskriminatif dari keluarga ODHA, masyarakat sekitar termasuk juga warga gereja yang memandang keberadaan ODHA sebagai ancaman yang membahayakan bagi kehidupan orang-orang disekitar mereka karena khawatir akan tertular. Sikap anggota keluarga, masyarakat yang mengisolir ODHA semakin memperburuk kondisi mereka. Kondisi ini menjadi salah satu penyebab kemarahan yang terjadi pada ODHA. Permasalahan lain yang juga perlu mendapat perhatian adalah ketika mereka

Healing and Wholeness :Asia Theological Perspective on HIV/AIDS: Assam: India, Bartataki and Company Pvt.Ltd, 2005, 1-2

3.Yayasan Sipritia, Lembaran Informasi tentang HIV/AIDS untuk orang yang hidup dengan HIV/AIDS, Jakarta: Yayasan Spiritia 2001, Hal 10 
putus asa dengan kondisi yang dialami, maka timbul keinginan untuk mengakhiri hidup dengan cara euthanasia. Karena itulah penulis merasa perlu untuk menuliskan topik ini supaya keberadaan ODHA tidak diabaikan dan dijadikan sebuah "ruang" pelayanan pastoral bagi gereja.

\section{PEMBAHASAN \\ 1. Gambaran umum HIV/AIDS a. Defenisi HIV/AIDS}

AIDS adalah singkatan dari Acquired Immune Deficiency Syndrome. Acquired berarti didapat, Immune berarti terkait dengan sistem kekebalan tubuh kita, Deficiency berarti kekurangan, Syndrome berarti penyakit dengan kumpulan gejala. Jadi AIDS berarti kumpulan gejala akibat kekurangan atau kelemahan sistem kekebalan tubuh . ${ }^{4}$ AIDS adalah suatu infeksi penyakit atau kumpulan gejala penyakit yang didapat karena penurunan daya tahan tubuh yang disebabkan oleh virus HIV (Human Imunnodeficiency Virus). Virus ini terdapat pada sebagian besar cairan tubuh manusia yang telah tertular. Virus tersebut memasuki sel-sel darah putih yang berfungsi untuk melindungi tubuh dari infeksi dan penyakit. Dalam sel-sel darah tersebut virus HIV merusak materi dasar genetika manusia (DNA dan RNA) secara permanen. Virus ini hanya terdapat di cairan tubuh manusia terutama pada konsentrasi sel darah putih. HIV baru bisa tertular apabila konsentrasi virus cukup banyak. Konsentrasi terbanyak di cairan darah, semen pada sperma laki-laki, cairan vagina dan sedikit banyak pada air susu ibu. Masa tunas virus ini cukup lama sekitar 3- 10 tahun, cepat lambannya seseorang terinfeksi AIDS tergantung dari gaya hidup dan pola makan. Ketika sel-sel darah ini menjadi rusak oleh HIV maka tubuh akan kehilangan daya tahannya serta gampang terinfeksi berbagai macam virus dan basil yang akan menimbulkan berbagai penyakit yang disebut penyakit "aportunistik". Bila daya tahan tubuh sudah sangat menurun maka penyakit yang ringan sekalipun akan membahayakan jiwa si pasien. Penyakit-penyakit tumpangan yang sering dialami seseorang yang telah ambruk daya tahan tubuhnya seperti : pneumonia paru akut, TBC, Hepatitis, jamur, diare akut, herpes zoster, kanker kulit, infeksi paru, infeksi jamur dalam mulut atau vagina dan berbagai penyakit kurang gizi akut lainnya. Kondisi seseorang

\footnotetext{
${ }^{4}$ Yayasan Spiritia, Lembaran Informasi tentang HIV/AIDS, Jakarta: Yayasan Spiritia,2001, hal 101-
}

yang sudah dalam keadaan ini yang disebut AIDS. ${ }^{5}$

\section{b. Asal Mula HIV/AIDS}

Gejala penyakit AIDS ditemukan pada tahun 1970-an di Afrika dan menyebar dan ditemukan di mana-mana dan diumumkan di Amerika Serikat pada tahun 1981. Semula penyakit ini ditemukan menyerang penduduk negara-negara Afrika Tengah di sekitar gurun Sahara. Tetapi karena rasa malu, pemerintah Afrika Tengah sering tidak mengakui kenyataan tersebut sehingga kasus yang dilaporkan sangat diperkecil angka-angkanya. Infeksi AIDS sebenarya sudah terlihat di Afrika sejak pertengahan tahun 70-an dan kelihatannya epidemi AIDS berasal dari sekitar danau Victoria di Afrika Timur yang ditularkan oleh sejenis kera hijau. Di negara Tanzania dan Uganda penyakit ini menyebar baik di daerah perkotaan maupun di daerah pedesaan. Sebagai contoh di sebelah barat daya Uganda, seluruh desa sudah terinfeksi. Dalam waktu yang relatif singkat, pada tahun 1983 ditemukan virus penyebabnya oleh Luc Montagnier dari Institut Pasteur Paris yang diberi nama lymphodenopathy Assosiated Virus (LAV). Pada waktu yang hampir bersamaan Robert Gallo dan Provic dari Laboratorium National Institut of Health di Bethesda, Maryland Amerika Serikat menemukannya pada tahun 1984 yang disebut Human T.Lymphotropic Virus type III (HTVL-

III) dan oleh J.Levy dari San Franscisco disebut Aids Related Virus (ARV). Kemudian pada bulan Mei 1986 Komisi International mengenai Taksonomi menggunakan istilah HIV sebagai Istilah yang umum dan selanjutnya istilah inilah yang selalu digunakan untuk menyebut virus HTVL atau LAV itu. Pada tahun 1985 ditemukan HIV serotip lain pada penderita AIDS yang pernah tinggal di Guinea Bissau, Afrika Barat. Karena itu virus yang terdahulu disebut sebagai HIV-I dan yang baru ditemukan sebagai HIV-2.

Nama AIDS pertama kali digunakan oleh Don Amstrong, kepala bagian penyakit infeksi dan Cancer Memorial Center- Sloan : New York. Penyebarannya terjadi karena hubungan pelaku homoseksual dari Afrika denga rekanrekan mereka di Haiti dan kemudian masuk ke Amerika Serikat di kalangan pelaku homoseksual. Deteksi adanya wabah ini di Indonesia sebenarnya sudah terlihat pada tahun 1983. Kemudian pertama diketahui pada tahun 1986 di Jakarta tetapi secara resmi baru diakui

\footnotetext{
${ }^{5}$ Emmy Sahertian dkk, Memahami..., hal 2-3
} 
keberadaanya di Indonesia dan terjadi di Bali pada tahun 1987 yang menimpa seorang turis berkebangsaan Belanda. ${ }^{6}$

\section{c. Gambaran Umum Penyebaran HIV/AIDS di Indonesia}

Seseorang yang telah tertular HIV tidak dengan serta merta akan mengalami kesakitan. Mereka tampak sehat seperti orang biasa lainnya. Penularan tahap awal ditandai dengan flu ringan yang kemudian sehat kembali. Hal ini disebabkan karena jumlah sel pertahanan tubuh masih cukup banyak untuk menjaga kesehatannya. Perlu pula diwaspadai akan "periode jendela" yaitu masa tunas virus HIV. Periode ini terjadi ketika seseorang baru tertular dan reaksi anti bodi tubuh belum mereplikasi bentuk virus yang ada. Biasanya bila diperiksa orang tersebut terindikasi HIV negatif. Periode pembentukan replikasi antibodi ini memakan waktu 3-10 minggu. Bahayanya adalah meskipun terindikasi negatif namun orang tersebut sudah dapat menularkan kepada orang lain. Kondisi yang demikian menyebabkan orang tidak menyadari akan statusnya dan risiko menularkan kepada orang lain. Penambahan jumlah penularan kepada orang lain itu yang di sebut "efek gunung es" artinya jumlah kasus yang kelihatan biasanya hanyalah puncak kecil di permukaan, sementara jumlah besar dibawah sangat banyak.

Permasalahan AIDS mulai menonjol di Indonesia setelah pada bulan April 1987 pertamakalinya ditemukan adanya AIDS di Bali pada seorang turis asal Belanda yang meniggal karena AIDS. Kasus AIDS kedua adalah seorang berkebangsaan Kanada yang sudah dua tahun tinggal di Indonesia meninggal karena pneumonia dengan tanda-tanda infeksi AIDS pada bulan November tahun yang sama. Kasus ketiga adalah pria Indonesia yang meninggal di Bali pada bulan Juni 1988. Sejak itu banyak korban ditemukan di luar Bali bahkan di seluruh Indonesia.

Secara resmi diberitakan bahwa AIDS sudah memasuki Indonesia pada tahun 1987, tetapi ada penelitian yang menyebutkan bahwa AIDS sudah ada di Indonesia sejak tahun 1983. Hal itu dibuktikan dengan adanya bukti dari pemeriksaan darah dari sekelompok waria penghuni Taman Lawang Jakarta. Hasil pemeriksaan laboratorium menunjukkan bahwa dari dua sampel darah waria yang diperiksa itu

\footnotetext{
${ }^{6}$ Herlianto, AIDS dan Perilaku Seksual, Bandung:
}

menunjukkan bahwa mereka berdua positif terinfeksi HIV/AIDS. Kedua waria itu mengaku bahwa mereka sering melayani tamunya baik tamu asing maupun tamu-tamu melayu.

Majalah Tempo tanggal 5 April 1986 sudah menurunkan berita utama berjudul "kini di Indonesia : AIDS, dan dalam laporannya menyebut bahwa pada tahun 1986 di Indonesia sudah ada beberapa orang yang terinfeksi AIDS bahkan sudah seorang ibu beranak tiga berumur 25 tahun yang meniggal karena AIDS. Korban ini boleh dikatakan sebagai korban pertama yang diketahui di Jakarta. Tempo juga menyebutkan bahwa setidaknya tahun itu sudah 10 orang dicurigai terifeksi AIDS yang telah diperiksa di Rumah Sakit Cipto Mangunkusumo Jakarta. Beberapa dari mereka adalah orang-orang yang bekerja sebagai Tenaga Kerja Indonesia (TKI) di luar negeri.

Selanjutnya AIDS menyebar dengan sangat pesat, hal itu dapat dilihat dari penyebarannya yang sudah mencapai ke 12 propinsi di Indonesia pada tahun 1993 dengan jumlah 111 kasus dan 23 orang sudah meninggal karena AIDS. Banyak orang di Indonesia masih beranggapan bahwa angka di atas masih dapat dikatakan belum apa-apa karena sangat kecil dibandingkan jumlah penduduk Indonesia yang pada saat itu mencapai 185 juta. Tetapi jika melihat sifat dari AIDS yang seperti gunung es, maka diperkirakan bahwa orang yang telah terifeksi AIDS pada tahun 1993 sudah mencapai sekitar 17.500. Sedangkan menurut WHO, angka penyebaran AIDS di Indonesia pada tahun 1993 adalah 20.000-30.000 orang. $^{7}$ Melihat penyebarannya yang demikian cepat maka tentu infeksi AIDS sekarang sudah sangat tinggi. Data kemeterian kesehatan RI sampai dengan bulan Desember 2017 menyebutkan bahwa angka infeksi HIV/AIDS di Indonesia mencapai 280.633 orang.

Penyebaran epidemi ini begitu cepat dan mengejutkan. Penyebaran virus ini sangat cepat karena virus ini menular dengan berbagai cara. Di Indonesia, ada beberapa cara penyebaran virus ini. Perilaku seks beresiko tinggi (risti) yang melakukan hubungan seks bukan dengan pasangannya tanpa kondom dan berhubungan seks dengan lebih dari satu orang apalagi teman kencannya itu telah terinfeksi HIV/AIDS, pemakai narkoba suntik.

\footnotetext{
${ }^{7}$ Herlianto
} 
Kebanyakan yang terinfeksi dengan cara ini adalah remaja-remaja yang telah kecanduan narkoba. Biasanya mereka memakai narkoba suntik ini secara bersama dan berbagi. Mereka mengumpulkan uang secara bersama (patungan) karena harga narkoba yang relatif mahal bagi anak-anak remaja ini. Biasanya juga jarum suntik yang mereka pakai adalah jarum suntik yang sama. Hal ini sangat memungkinkan cepatnya virus HIV menyebar ke banyak orang. Karena jika seseorang pemakai sudah terinfeksi HIV/AIDS dan ikut tergabung dalam kelompok pemakai narkoba suntik ini maka sekelompok orang yang bergabung dengannya pastilah akan terifeksi juga. Penyebaran yang lainnya bisa dari suami yang sudah terinfeksi dan menularkannya kepada isterinya atau sebaliknya istri menularkannya kepada suaminya. Orang tua yang sudah terinfeksi menularkannya kepada anak mereka melalui pemberian ASI kepada bayi mereka.

\section{Masalah-masalah yang Muncul pada ODHA karena AIDS}

\section{a. ODHA dan Kemarahan}

Reaksi pertama dari mereka yang terdiagnosa positip AIDS adalah marah, shock, menyangkal (denial) dan tidak percaya. Tahap berikut setelah menerima kenyataan itu adalah masa dimana reaksi emosional yang kuat muncul seperti kemarahan yang meluap-luap, ketakutan, dan sedih. Dalam kondisi yang demikian ODHA membutuhkan dukungan agar bisa menerima kenyataan yang ada dan dapat melanjutkan kehidupannya. Dalam keadaan yang demikian, ODHA menghadapi masalah yang baru di dalam dirinya yang muncul sebagai bentuk emosi yang negatif yang termanifestasi dalam bentuk kemarahan, ketakutan, depresi, karena penyakitnya tidak bisa disembuhkan sehingga tidak jarang muncul keinginan untuk melakukan euthanasia. Mereka merasa seolah-olah dipisahkan dari ikatan dengan Tuhannya. Mereka menyimpan kemarahan tersendiri kepada Tuhan karena penyakit yang mereka alami. Ada kecenderungan bertanya dengan ungkapan, "apa salahku Tuhan"? Ketakutan dan depresi yang mereka rasakan sering kali berubah menjadi kemarahan yang berdampak fatal. Banyak dimensi kemarahan yang bergejolak di dalam hati mereka. Kemarahan itu tertuju kepada diri sendiri karena masa lalunya yang "gelap" yang menyebabkan penyakitnya sekarang, kepada orang yang menyebabkan dirinya terinfeksi penyakit itu, juga kemarahan kepada keluarga dan orang disekitarnya yang menolak keberadaan mereka dan memperlakukan mereka dengan sadis. ${ }^{8}$

Kemarahan memang menjadi fenomena yang sering muncul dalam sikap orang-orang yang terinfeksi HIV/AIDS. Sudah ada contoh bahwa seorang yang terinfeksi membunuh orang yang menularkan virus itu kepadanya dan ada juga yang memutuskan untuk menularkannya kepada orang lain agar tidak hanya dirinya sendiri yang terinfeksi, ini adalah salah satu wujud dari kemarahan. Kemarahan mereka memuncak ketika menerima perlakuan yang diskriminatif serta stigmatisasi dari lingkungan mereka. ${ }^{9}$ Banyak orang yang tidak memahami dengan benar apa dan bagaimana HIV/AIDS akan memiliki kecenderungan sikap yang diskriminatif dan mendiskreditkan ODHA. Seperti yang dialami oleh Bunga (nama samaran) salah seorang ODHA yang berusia 28 tahun. Wanita yang diketahui mengidap HIV/AIDS sejak tahun 2004 ini mengaku mendapat perlakuan diskriminatif dari keluarganya sendiri. Sejak diketahui mengidap HIV bunga dijauhi oleh masyarakat. Yang paling menyedihkan adalah, para tetangga dan temantemannya selalu berpura-pura tidak kenal. Bunga semakin apatis ketika keluarga mengucilkannya. Bunga terpaksa tidur di kamar sendiri dan menggunakan peralatan makan khusus. Bila ada sanak saudara yang datang, Bunga tidak diperbolehkan mendekatinya dan dilarang bermain dengan anak-anak mereka. Semua perlakuan ini menjadi salah satu penyebab bergejolaknya kemarahan di dalam hati Bunga. Perlakuan seperti yang dialami Bunga dialami oleh hampir semua ODHA. ${ }^{10}$ Karena itu, perlu dikembangkan pelayanan pendampingan yang dalam hal ini kita sebut pendampingan pastoral.

\section{b. ODHA dan Permohonan Euthanasia}

Euthanasia berasal dari kata Yunani dengan asal kata $e u=$ baik, tanpa rasa derita; thanatos $=$ kematian, maut; euthanateo $=$ mati dengan mudah, bahagia. Dengan demikian pengertian euthanasia adalah kematian yang baik atau kematian yang indah tanpa derita. ${ }^{11}$ Ensiklopedi Indonesia menunjukkan bahwa

\footnotetext{
${ }^{8}$ Emmy Sahertian dkk, Memahami HIV dan AIDS,

Panduan untuk para Pendeta dan Pengajar, Jakarta:

Kalangan sendiri, 2002, hal 26-27

${ }^{9}$ Ibid, hal 26-33

${ }^{10}$ Linda, Stop Diskriminasi ODHA, Medan : Harian

Waspada, 2006, 14

${ }^{11}$ Piet Go ). Carm, Hidup dan Kesehatan, Malang:
} 
STFT Widya Sasana, 1984, 346 
euthanasia diberlakukan dalam dunia kedokteran sebagai pertolongan medis agar kesakitan atau penderitaan yang dialami seseorang diringankan. ${ }^{12}$

Tuhan menuntut agar setiap orang menghormati dan menghargai hidup. Dalam hukum taurat yang ke-enam, Tuhan melarang manusia untuk membunuh. Tuhan memanggil setiap orang untuk menerima anugerah yang berupa hidup. Tuhan melarang manusia menolak hidupnya sendiri atau bunuh diri sebab hidup manusia bukanlah miliknya sendiri. Itu milik Tuhan. Kekuasaan Tuhan atas hidup dan mati bukanlah terletak di tangan manusia, melainkan di tangan Tuhan. Tetapi kepada manusia telah Tuhan letakkan tanggungjawab atas hidupnya sendiri. Manusia mempunyai kebebasan mengenai hidupnya sendiri, tetapi kebebasan itu disertai dengan suatu tanggungjawab. Ia bertanggungjawab kepada Tuhan atas segala apa yang diperbuatnya terhadap hidupnya. Manusia tidak dapat menolak karunia yang disebut hidup itu, sebab menolak hidup adalah bunuh diri. Dalam Alkitab, perbuatan bunuh diri dipandang sebagai pelanggaran firman Tuhan. Disebutkan ada tiga peristiwa bunuh diri. Saul bunuh diri karena ia tidak taat kepada Tuhan (1 Sam 31). Akhitofel, penasehat raja daud bunuh diri karena ia menghianati raja Daud dan memihak kepada Absalom tetapi ternyata sia-sia belaka (2 Sam 17:23). Yudas Iskariot bunuh diri (Kis.1:16) setelah menghianati Yesus. Bunuh diri tidak selalu timbul dari motif-motif yang sama. Tetapi bagaimanapun juga perintah Tuhan dan contohcontoh Alkitab jelas menunjukkan bahwa bunuh diri itu adalah dosa yang sangat berat terhadap Tuhan. Dia sang pemberi hidup adalah satusatunya yang berdaulat atas hidup manusia. Siapa yang bunuh diri secara sadar atau tidak sadar, terpaksa atau tidak terpaksa, dalam keadaan sakit atau sehat dan dalam keadaan apapun, ia telah merusak kedaulatan Allah atas hidup. Ketiga contoh itu menyatakan kepada kita betapa dalamnya dan beratnya dosa itu. ${ }^{13}$

Permohonan euthanasia di kalangan ODHA bisa dipicu oleh stress dan depresi yang mereka alami. Stress yang terjadi merupakan suatu proses adaptasi atau penyesuaian terhadap ancaman yang menimpa diri mereka di mana mereka menyadari bahwa mereka akan mati

\footnotetext{
${ }^{12}$ Hasan Shadily, Ensiklopedi Indonesia, Jakarta: 1980, 978

${ }^{13}$ J.Verkuyl, Etika Kristen: Kapita Selekta, Jakarta : BPK Gunung Mulia, 1982, 214-218
}

karena AIDS dan juga merupakan adaptasi terhadap peristiwa-peristiwa yang tidak menyenangkan yang mereka alami dari lingkungan dan orang-orang di sekitar mereka. ${ }^{14}$ Pemicu yang lain adalah depresi. Depresi yang berasal dari rasah bersalah yang bermula dari perasaan berdosa dan ketidaktaatan yang menyebabkan mereka terinfeksi. Depresi tersebut termanifestasi dalam bentuk perasaan murung, tida ada harapan, kecewa, sedih dan lesu. Depresi sendiri dicirikan oleh beberapa hal. Kita dapat belajar dari contoh nabi Elia dalam kitab I Raja-raja 19. Nabi Elia menjadi takut (ayat 3) kesepian (ayat 10), sangat sedih dan kecewa, sehingga ia tidak dapat melakukan apaapa dan ia ingin mati saja (ayat 4$)^{15}$ Penyakit yang tidak mungkin disembuhkan, stigma dari masyarakat dan perlakuan yang diskriminatif dari orang-orang sekitar dan keluarga dekat semakin memperburuk kondisi stress dan depresi mereka yang akhirnya semakin menguatkan keinginan untuk melakukan euthanasia.

\section{ODHA sebagai "Ruang" Pastoral Gereja a. Kepedulian Pastoral}

Kepeduliaan pastoral dan pelayanan pastoral menjadi alat yang penting sekali yang membantu gereja menjadi pos penyelamat jiwa, tempat berlindung, dan taman kehidupan rohani. Pelayanan pastoral dapat membantu menyelamatkan kehidupan yang menderita kerusakan dalam badai hidup sehari-hari, yang hancur karena rasa cemas, rasa bersalah, rasa marah dan persoalan-persoalan lainnya. Pelayanan pastoral mengurangi kelumpuhan warga gereja untuk menerima kasih dan pelayanan pastoral juga terus berupaya menjadi alat pembaharu melalui perdamaian yang membantu menyembuhkan keterasingan orang dari diri sendiri, keluarga dan orang lain di sekitarnya. ${ }^{16}$ Keberadaan ODHA telah menjadi "ruang" pastoral gereja sebab stigmatisasi masyarakat telah "membawa" mereka pada posisi "diasingkan". Karena itu mari kita bertolak dari apa yang dilakukan oleh Yesus dalam "aksi pastoralNya", dimana apa yang Ia

\footnotetext{
${ }^{14}$ E.P.Gintings, Mengantisipasi Stress dan

Penanggulangannya, Yogyakarta: Yayasan ANDI, 1999, hal 5-7

${ }^{15}$ Gary R. Collins, Konseling Kristen Yang Efektif,

Malang: SAAT, 2000, hal136-139

16 . Howard Clinebell, Tipe-tipe dasar Pendampingan Pastoral, BPK Gunung Mulia- Kanisius, 2002,15-18
} 
kerjakan terhadap orang-orang pada zamanNya merupakan suatu proses pendampingan bahkan kepada mereka yang terasingkan karena kusta (Mat.8:1-3). Ia tidak hanya melihat mereka beberapa menit saja. Ia melewatkan waktu sambil menolong mereka mengatasi masalahmasalah hidup dengan perhatian yang dalam. Ia tidak hanya melihat kesulitan-kesulitan mereka tetapi Ia juga melihat kemampuan mereka dan pengharapan-pengharapan yang mereka miliki. ${ }^{17}$

\section{b. Fungsi-fungsi pelayanan pastoral}

Dalam pendampingan/pelayanan pastoral yang dilakukan oleh gereja dikenal empat fungsi yang selalu dipakai untuk menolong. Pertama, pelayanan pastoral berfungsi untuk menyembuhkan. Dalam pengertian ini, menyembuhkan dimaksudkan sebagai kemungkinan adanya dampak-dampak positif yang timbul dari relasi pastoral dan demi pengutuhan atau integrasi seseorang berhubungan dengan kesehatan rohani dan kesejahteraannya dalam arti yang luas. Clebsch dan Jaekle mengatakan demikian: "penyembuhan adalah fungsi pastoral yang bermaksud mengatasi ketidakseimbangan seseorang dengan mengembalikan keutuhannya dan menuntun dia maju melebihi kondisinya yang sebelumnya. Fungsi ini berakar pada kitab suci yang mengacu kepada Keluaran 15:26, "Akulah, Tuhan yang menyembuhkan engkau". Yesus juga menganggap berkhotbah dan menyembuhkan sebagai tugas-Nya (Mat.9:35). ${ }^{18}$

Kedua, pendampingan pastoral berfungsi untuk menopang. Dalam hal ini menopang dimaksudkan sebagai penghiburan dan penguatan yang dirasakan manusia dari relasi pastoral sewaktu ada kesusahan oleh karena mereka mengalami kehilangan, rasa sedih dan penderitaan. Kitab suci mengenal pelbagai kata menghibur. Dalam Perjanjian Lama kata nicham secara harfiah berarti "membuat bernafas lagi" dalam situasi tertekan dan sesak. Dalam Perjanjian Baru, istilah paraklein punya arti menegur dan menghibur, keduanya mengandung arti membangkitkan. Clebsch dan Jaekle membedakan menopang dalam empat tugas. Pertama tugas penjagaan untuk mendukung orang yang telah mengalami sebuah kehilangan agar ia tidak tenggelam terlalu jauh dan

\footnotetext{
${ }^{17}$ Norman Wright, Konseling Krisis, Gandum Mas :1996, 34-39

${ }^{18}$ William A.Clebsch and Charles R.Jaekle, Pastoral Care in Historical Perspective, London: Jason Aronson Inc, 1994, 33-34
}

kesedihan sebisa mungkin diatasi. Kedua, penghiburan sejauh penderita terbuka terhadapnya. Ketiga, pemantapan yang berusaha mengerahkan dan menyusun kembali sisa tenaganya agar orang itu sendiri dapat menangani situasi itu. Tugas terakhir adalah pemulihan bila orang itu mulai membangun rencana hidup yang baru agar berpangkal pada situasi yang baru. ${ }^{19}$ Ketiga, pendampingan patoral berfungsi untuk membimbing. Dalam hal ini membimbing dimaksudkan tuntunan yang dapat timbul dari relasi pastoral yang membuat manusia merasa didukung agar berdasarkan pandangan hidupnya membuat pilihan dan mengambil keputusan dan dengan demikian berkembang dalam hal berfungsinya rohani secara mandiri. Clebsch dan Jaekle memberikan rumusan membimbing sebagai fungsi pelayanan yang merawat jiwa-jiwa dengan mencapai kebijaksanaan tertentu berhubungan dengan apa yang harus dilakukan seseorang berhadapan dengan masalah berat untuk memilih di antara pelbagai kemungkinan pemikiran atau tindakan. ${ }^{20}$ Keempat, pendampingan pastoral juga berfungsi untuk mendamaikan. Dalam hal ini mendamaikan dimaksud adanya kemungkinan makna relasi pastoral bagi manusia yang telah terasingkan satu sama lain dan dari dirinya sendiri atau dari Allah agar menemukan kembali dirinya, mengalami penerimaan dan pengampunan dan dengan demikian mulai belajar hidup dengan relasi-relasi baru. Fungsi ini ditandai dengan adanya pelayanan pengampunan yang berlatar belakang dosa dan rasa bersalah dan kemarahan yang belum terselesaikan (2 Kor. 5:18) ${ }^{21}$. Selain mengalami keterasingan dari orang sekitar, ODHA juga menyimpan kemarahan sebagai akibat dari perlakuan yang diskriminatif dari orang-orang disekitar bahkan kepada orang-orang yang menyebabkan mereka terinfeksi HIV/AIDS karena itu mereka sangat membutuhkan pelayanan ini.

Seward Hiltner, seorang teolog pastoral dari Princeton Theology Seminary menawarkan konsep fungsi pastoral dalam tiga hal yakni : menyembuhkan, menopang dan membimbing. Di kemudian hari, Clebsch dan Jaekle menambahkan satu hal yang sangat vital dalam

\footnotetext{
${ }^{19}$ Gerben Heitink, Fungsi-fungsi..., hal14-15

${ }^{20}$ William A.Clebsch and Charles R.Jaekle, Pastoral

Care in Historical Perspective, London: Jason

Aronson Inc, 1994, 42-46

${ }^{21}$ Gerben Heitink, Fungsi-fungsi..., hal 25
} 
pendampingan pastoral yaitu

fungsi pendamaian. Selanjutnya, pada perkembangan berikutnya Howard .J. Clinebell merasa perlu menambahkan fungsi pemeliharaan sebagai fungsi vital dalam pendampingan pastoral. Dan akhirnya, belakangan dikembangkan fungsi menguatkan oleh para teolog pastoral. Fungsifungsi pendampingan pastoral ini juga sangat relevan untuk dihadirkan dalam upaya menghadirkan kepedulian pastoral terhadap ODHA yang dapat difasilitasi oleh gereja secara umum dan pendeta, konselor secara partikular. ${ }^{22}$

\section{IV.KESIMPULAN.}

Donald Messer mengatakan stigmatisasi dan diskriminasi terhadap mereka membuat ODHA tidak hanya mati tetapi mati dalam kesendirian. Bagaimana hal ini dilihat dari kacamata Alkitab. Matius 25:36a "ketika Aku sakit kamu melawat Aku...". Pelayanan dan pendampingan pastoral gereja merupakan salah satu cara untuk menolong mereka. Menjadikan HIV/AIDS sebagai "ruang" sekaligus tema pelayanan pastoral gereja adalah salah satu implementasi dari konsep tersebut.

Dibutuhkan keseriusan untuk mendorong supaya persoalan HIV/AIDS secara urgen menjadi salah satu tema pelayanan pastoral. HIV/AIDS sudah menjadi persoalan kemanusiaan maka itu berarti itu juga telah menjadi persoalan bagi gereja dan bahkan persoalan bagi semua agama di muka bumi ini. Ketika kita bersepakat untuk menjadikan persoalan HIV/AIDS sebagai persoalan kemanusiaan, maka sudah seharusnya hal itu menjadi tanggungjawab kita bersama termasuk gereja. Tidak ada alasan bagi gereja untuk menolak jika ada tuntutan dan desakan untuk melihat dan menjadikan persoalan HIV/AIDS sebagai persoalan pelayanan pastoral.

22 A.Wati Longchar (ed) Compassion and Care for the HIV/AIDS Infected and Affected dalam buku :Health, Healing and Wholeness :Asia Theological Perspective on HIV/AI..

Sekarang tentu kita bisa bertanya "di mana titik singgung antara persoalan-persoalan HIV/AIDS dengan pelayanan pastoral?". Menurut saya, salah satu titik singgungnya terletak pada bagaimana gereja mengimplementasikan fungsi-fungsi pelayanan pastoral dalam menghadapi berbagai kondisi yang dialami oleh ODHA. HIV/AIDS dan ODHA menjadi ruang untuk mengimplementasikan fungsi-fungsi pelayanan pastoral seperti telah diuraikan diatas. Fungsi menyembuhkan dalam pelayanan pastoral tentu tidak harus dipahami dalam pengertian penyembuhan fisik. Upaya penyembuhan psikis karena adanya stigmatisasi negatif dan penolakan dari masyarakat justru akan besar pengaruhnya terhadap kondisi ODHA. Begitu pula dengan rekan sekerja/sepelayanan atau keluarga dari ODHA yang telah menderita dengan sangat parah bahkan jika telah meninggal, tentu bisa saja mengalami dukacita dan luka batin yang biasanya berakibat pada psikomatis Dalam kondisi yang indah ini orang yang menderita dapat dibawa pada hubungan yang indah dengan Tuhan. Fungsi membimbing dalam pelayanan pastoral tentu akan sangat penting artinya bagi semua warga gereja khususnya ODHA dalam menghadapi berbagai aspek persoalannya. Warga gereja dibimbing dan saling membimbing supaya tidak tertular HIV/AIDS. Seseorang yang telah divonis sebagai ODHA tentu juga sangat membutuhkan bimbingan untuk keluar dari kebingungan dan kesulitannya. Ia mesti dibimbing untuk dapat memilih atau mengambil keputusan yang benar dan bertanggungjawab. Fungsi menopang akan sangat bermanfaat, secara khusus bagi ODHA untuk dapat bertahan dalam situasi krisis yang mendorongnya untuk melakukan euthanasia.

Situasi krisis juga bisa terjadi pada keluarga, rekan sekerja/sepelayanan dari ODHA. Krisis bisa terjadi misalnya karena adanya penolakan dari lingkungan sekitar terhadap ODHA. Dalam kondisi ini, topangan sekurangkurangnya dapat berupa kehadiran dan sapaan yang menyejukkan serta sikap terbuka terhadap 
ODHA akan mengurangi penderitaan yang dialami oleh ODHA. Fungsi mendamaikan akan sangat bermanfaat bagi upaya untuk membangun kembali hubungan-hubungan yang rusak yang telah melibatkan ODHA. Kemarahan, rasa benci, dendam, depresi, ketidakstabilan emosi, stigmatisasi negatif, pengucilan, bisa merusak hubungan kemanusiaan, bahkan mungkin hubungan dengan Tuhan. Fungsi mengutuhkan kehidupan manusia merupakan inti sekaligus tujuan utama dari pelayanan pastoral. Bahwa kerusakan, keretakan, kehancuran dan kebobrokan yang menyebabkan penderitaan merupakan lawan dari keutuhan. Bahwa pelayanan pastoral terhadap warga gereja pada akhirnya dimaksudkan sebagai upaya untuk membangun keutuhan. Keutuhan sebagai manusia ciptaan yang segambar dan serupa dengan Allah dan juga keutuhan sebagai warga gereja dan sekaligus sebagai tubuh Kristus.

\section{Daftar Pustaka}

[1] A.Wati Longchar (ed) Compassion and Care for the HIV/AIDS Infected and Affected dalam buku :Health, Healing and Wholeness :Asia Theological Perspective on HIV/AIDS: Assam: India, Bartataki and Company Pvt.Ltd, 2005

[2] Emmy Sahertian dkk, Memahami HIV dan AIDS, Panduan untuk para Pendeta dan Pengajar,

Jakarta: Kalangan sendiri, 2002

[3] E.P.Gintings, Mengantisipasi Stress dan Penanggulangannya, Yogyakarta: Yayasan ANDI, 1999

[4] Gary R. Collins, Konseling Kristen Yang Efektif, Malang: SAAT, 2000

[5] Gerben Heitink, Fungsi-fungsi Pokok Pemeliharaan Pastoral, Yogyakarta: Pusat Pastoral Yogyakarta: 2001

[6] Hasan Shadily, Ensiklopedi Indonesia, Jakarta: 1980
[7] Herlianto, AIDS dan Perilaku Seksual, Bandung: Yayasan Kalam Hidup, 1995

[8] Howard Clinebell, Tipe-tipe dasar Pendampingan Pastoral, BPK Gunung Mulia-Kanisius, 2002

[9] J.Verkuyl, Etika Kristen: Kapita Selekta, Jakarta : BPK Gunung Mulia, 1982

[10] Linda, Stop Diskriminasi ODHA, Medan : Harian Waspada, 2006

[11] Norman Wright, Konseling Krisis, Gandum Mas :1996

[12] Piet Go. Carm, Hidup dan Kesehatan, Malang: STFT Widya Sasana, 1984

[13] William A.Clebsch And Charles R.Jaekle, Pastoral Care In Historical Perpective, London: Jason Aronson Inc. 1994

[14] Yayasan SPIRITIA, Pasien Berdaya - Seri Buku Kecil, Jakarta: Yayasan SPIRITIA, 2001

[15] Yayasan Sipritia, Lembaran Informasi tentang HIV/AIDS untuk orang yang hidup dengan HIV/AIDS, Jakarta: 2001

[16] Yayasan Spiritia, Lembaran Informasi tentang HIV/AIDS, Jakarta: Yayasan Spiritia,2002 